\title{
Synchronism of naupliar development of Sacculina carcini Thompson, 1836 (Pancrustacea, Rhizocephala) revealed by precise monitoring
}

\author{
Fabien Trédez, Nicolas Rabet, Laure Bellec and Fabienne Audebert ${ }^{*}$ (1)
}

\begin{abstract}
Sacculina carcini is member of a highly-specialized group of parasitic cirripeds (Rhizocephala) that use crabs (Carcinus maenas) as hosts to carry out the reproductive phase of their life cycle. We describe the naupliar development of $S$. carcini Thompson, 1836 from a very precise monitoring of three different broods from three specimens. Nauplii were sampled every $4 \mathrm{~h}$, from the release of the larvae until the cypris stage. Larval development, from naupliar instar 1 to the cypris stage, lasts $108 \mathrm{~h}$ at $18^{\circ} \mathrm{C}$. A rigorous sampling allowed us to describe an additional intermediate naupliar instar, not described previously. Naupliar instars are renumbered from 1 to 5. Nauplius 1 (N1) larvae hatch in the interna; N2 are released from the interna and last between 12 and 16 h; N3 appear between 12 and $16 \mathrm{~h}$ after release; N4 appear between 28 and 32 h; and N5 appear between 44 and 48 h. The cypris stage appears between 108 and $112 \mathrm{~h}$. The redescribed morphologies allowed us to identify new characters. Antennular setation discriminates naupliar instars 3, 4 and 5. Telson and furca morphologies discriminate all naupliar instars. Furthermore, we demonstrate that the speed of larval development is similar within a single brood and between broods from different specimens, suggesting synchronization of larval development. From precise monitoring of broods every $4 \mathrm{~h}$, we demonstrate that the life cycle of S. carcini includes five instars of naupliar larvae instead of four. The morphological characters of the larvae discriminate these naupliar instars and allow the identification of S. carcini from other Rhizocephala species. S. carcini larvae develop synchronously. Consequently, they might be an informative model to study larval development in crustaceans.
\end{abstract}

Keywords: Synchronous development, Nauplius larva, Parasite, Lecithotrophy, Pancrustacea, Rhizocephala

\section{Background}

Sacculina carcini is a highly specialized barnacle parasite of several Brachyura crabs including the green crab Carcinus maenas [1]. It belongs to the Rhizocephala, all of which present a highly altered morpho-anatomy at the adult stage, related to their endoparasitic lifestyle. The female adult consists of a root system that colonizes the crab cavity and is connected by a stalk running through the integument

\footnotetext{
*Correspondence: fabienne.audebert@upmc.fr

Département des milieux et peuplements aquatiques, Muséum National d'Histoire Naturelle, UMR BOREA 7208 MNHN/UPMC/CNRS/IRD, Université Pierre et Marie Curie, Sorbonne Universités, 43, rue Cuvier, CP26, 75005 Paris, France
}

of the pleon to an external reproductive sac, the externa. One or two males take up residence inside the externa and develop into testes enclosed in the sac. Nauplius larvae are released by contractions of the externa and develop after several molts into a cypris larval stage, which metamorphoses into an adult after fixation on a suitable host crab.

The systematic positions of S. carcini and other Rhizocephala have been enigmatic. The first report of Sacculina is by Cavolini [2] who recognized Sacculina nauplii as one-eyed organisms, and grouped them with crustaceans. Thompson [3] described the S. carcini adult as a parasite and noted its affinity with cirripeds by studying the nauplius larvae. 
Currently, larval descriptions are still useful to identify and compare Rhizocephala species, primarily because specific adult taxonomic characters are scarce $[4,5]$. Four naupliar instars have been described for $S$. carcini $[6,7]$, but several descriptions of other Rhizocephala species count five naupliar instars: Briarosaccus tenellus [8], Polyascus polygenea [9], Sacculina pilosella [10], Peltogasterella gracilis and P. sulcata [11], and Heterosaccus papillosa [12]. The number of naupliar instars in Rhizocephala is a matter of some debate $[11,13]$ and our aim was to monitor larval development precisely to determine the exact number of naupliar instars.

In this study, we reared S. carcini specimens on green crabs over a period of several months in order to obtain several larval broods. Larvae of single broods were sampled every $4 \mathrm{~h}$, which allowed a precise description of the larval development.

\section{Methods}

\section{Collection of Sacculina parisitized crabs}

Carcinus maenas crabs parasitized by $S$. carcini were collected by hand during autumn 2012 and spring 2013 at Saint-Malo, Brittany, France $\left(48^{\circ} 40^{\prime} 33^{\prime \prime} \mathrm{N}, 1^{\circ} 59^{\prime} 9^{\prime \prime} \mathrm{W}\right)$, on the high level of Fucus serratus tidal belt. They were transported at ambient temperature to Paris in polystyrene boxes containing Fucus algae, without seawater.

\section{Maintenance of Sacculina-parisitized crabs}

Parisitized crabs were maintained in artificial seawater (salinity of $35 \mathrm{~g} / \mathrm{L}$, Instant Ocean, Aquarium Systems, Eastlake, Ohio), in a $160 \mathrm{~L}$ aquarium with a filtration system, which consists of a filter grid beneath a layer of gravel at the bottom of the aquarium, and prevents the aspiration of Sacculina larvae.

This system is composed of two different water circuits. In the first, water is aspirated at low flow rates through the gravel layer by a filter pump (Superfish AquaPro QS $400,1000 \mathrm{~L} / \mathrm{h})$. In the second, water is circulated to the surface through a tube containing a bubbling stone connected to an air supply to provide aeration. Both systems cause suspended particles to be gently drawn to the bottom of the aquarium and degraded naturally by bacteria. The water temperature was maintained at $18{ }^{\circ} \mathrm{C}$ (the nominal temperature of seawater at the northern coast of France during the summer) by a water thermoregulator (Teco TC10). The aquarium contained between 15 and 20 crabs. A total of 64 crabs were maintained in total, and fed with mussels three times per week.

\section{Sampling of S. carcini larvae}

Thirty-four single broods of $S$. carcini were obtained directly from aquaria containing Sacculina-parasitized crabs at $18{ }^{\circ} \mathrm{C}$, by checking with a light source placed at the corner of the aquarium three times per day. Samples were collected for $10 \mathrm{~min}$ at the light source where the larvae concentrated due to their positive phototropism and transferred with pipettes to vessels containing filtered natural seawater. The direct release of larvae from $S$. carcini externae was observed three times and these larvae were sampled immediately. Nine broods were obtained prematurely in stress conditions, by removing the crab from the water and touching the ostiole in the externa with a needle and then reimmersing the crab and collecting the larvae directly.

\section{Raising S. carcini larvae}

Twenty-seven broods were sampled as soon as they were observed to identify the first naupliar instar. Seven broods were allowed to mature to the cypris stage. Larvae were transferred to a $0.5 \mathrm{~L}$ glass vessel containing natural seawater filtered through a $150 \mu \mathrm{m}$ pore filter. Vessels were covered with perforated aluminium foil and placed in an $18{ }^{\circ} \mathrm{C}$ incubator without light. Seawater was changed every 24 or $48 \mathrm{~h}$, depending of the density of larvae. For three of the broods, larvae were sampled every $4 \mathrm{~h}$ until the cypris stage. The other four broods were sampled less regularly in order to confirm the development chronology. For each instar, the time indicated in hours corresponded to the duration since the larvae were released.

\section{Fixation and preservation of larvae}

For each sampling, an aliquot of about 100 larvae (nauplii or cypris) was fixed in $1 \%$ formalin. Larvae used for measurements and observations were rinsed three times (20 min each) in phosphate buffer saline (PBS), then preserved by transferring them through three ethanol baths (25, 50 and $70 \%)$, for 20 min each.

\section{Terminology}

Naupliar instars are numbered from nauplius 1 (N1) to nauplius 5 (N5) (Table 1), as for Polyascus polygenea [9]. Larvae were referred to as "early" if just after the molt and "late" if just before the next molt. The method of counting antennulary setae may vary according to the publications. Walossek et al. [8], Rybakov et al. [11] and Ponomarenko et al. [12] numbered antennulary setae from S1 for the preaxial seta to S5 for the postaxial seta. Collis and Walker [7] numbered from postaxial to preaxial. We decided to number from preaxial to postaxial setae. We used the term "portions" to designate the subdivisions of the antennules [8].

\section{Sexes of broods}

For seven broods, live cypris larvae were relaxed for $10 \mathrm{~min}$ in seawater containing tricaine mesylate (MS-222) 
Table 1 Terminology reported for the naupliar instars of different species

\begin{tabular}{|c|c|c|c|c|}
\hline \multirow[t]{2}{*}{ Larval instar } & \multicolumn{4}{|l|}{ Species } \\
\hline & $\begin{array}{l}\text { S. carcini } \\
\text { (This study) }\end{array}$ & S. carcini $^{\mathrm{a}}$ & $\begin{array}{l}\text { Briarosaccus } \\
\text { tenellus }^{\mathbf{b}}\end{array}$ & $\begin{array}{l}\text { Polyascus } \\
\text { polygeneac, }^{\mathrm{c}} \text { Sacculina } \\
\text { pilosella }^{\mathrm{d}}, \\
\text { Peltogaste- } \\
\text { rella gracilis }^{\mathrm{e}} \text {, } \\
\text { Heterosaccus } \text { papillosus }^{\mathrm{f}}\end{array}$ \\
\hline First instar & N1 & N1 & No & N1 \\
\hline Second instar & $\mathrm{N} 2$ & N2 & N1 & N2 \\
\hline Third instar & N3 & & N2 & N3 \\
\hline Fourth instar & N4 & N3 & N3 & N4 \\
\hline Fifth instar & N5 & N4 & N4 & N5 \\
\hline
\end{tabular}

NO-N5 naupliar instars 0-5

a Walker [6], Collis and Walker [7]

b Walossek et al. [8]

c Korn et al. [9]

d Korn and Rybakov [10]

e Rybakov et al. [11]

f Ponomarenko et al. [12]

[14] before fixation in order to extend the antennules and thus determine the sex of the larva by the morphology of their antennular aesthetascs $[14,15]$.

\section{Identification, drawing, and measurement of the larval instars}

A minimum of 20 PBS-rinsed larvae from each 4-hr sample were placed in depression slides and observed with an optical microscope to identify the larval instar. We measured naupliar instars from one brood of male larvae and one brood of female larvae. Dimensions of the larvae digitally photographed at $10 \times$ magnification were measured using AnalySIS Work v.5 software (Olympus SZX7 associated with DP 20 camera). Nauplii larvae were measured for maximal length and for width without the frontal horns. The furcae were also measured for length and for maximal width at their base. Cypris larvae were measured for maximal length. Measurements were calibrated with a micrometric slide.

To produce larval drawings, larvae rinsed in PBS were slightly crushed between a slide and coverslip to observe the antennulary setae, and traced at $400 \times$ magnification with Lucida camera (Wild M20). Lines were thickened and the tracings were then scanned.

\section{Scanning electron microscopy (SEM)}

Larvae preserved in $1 \%$ formalin were washed with PBS, placed in $74 \mu \mathrm{m}$ mesh size inserts (Netwell, Corning, Pittston, Pennsylvania), and progressively dehydrated in 30-min baths of ethanol (30, 50, 70, 95\%, and three times in $100 \%)$. They were progressively passed from $100 \%$ ethanol to 20-min baths of hexamethyldisilazane (SigmaAldrich, Gillingham, United Kingdom) at 30\% and 70\%, and two times in $100 \%$. Larvae were dried in a fume hood for $5 \mathrm{~min}$ and preserved in a desiccation chamber.

Larvae were mounted on stubs and then sputter-coated in gold (108 Manual Sputter Coater, Ted Pella Inc., Redding, California). The SEM observations were performed with a TESCAN-VEGA-II-LSU scanning electron microscope (courtesy of the Direction des Collections SEM facility of the Muséum National d'Histoire Naturelle, Paris) with an accelerating voltage of $15 \mathrm{kV}$. Electron micrograph images were taken with an Everhart-Thornley detector.

\section{Statistical analyses of larval instar dimensions}

Larval instar dimensions were analysed using $\mathrm{R}$ software [16]. Results were considered statistically significant at $\mathrm{p} \leq 0.05$. To verify the sexual dimorphism of $S$. carcini naupliar larvae, the dimensions of fixed male and female larvae from broods that had been retrospectively sexed at the cypris stage were measured at instars N2-N5 ( $n=25$ per instar). The measurements for each characteristic were pooled and their normal and homoscedastic distributions were tested $[17,18]$. Differences between the dimensions of male and female larval instars were analysed by the Kruskal-Wallis test [19] and a post hoc test [20], using the "agricolae" package [21].

\section{Results}

\section{Sex-specific dimensions of S. carcini larvae}

In single-sex broods, the measurements for each characteristic and each stage were distributed normally, which was consistent with populations containing a single sex. Males were significantly longer and wider at each naupliar instar $(\mathrm{N} 2-\mathrm{N} 5)$ than females $(\mathrm{p}<0.0001)$ (Table 2). Male furcae were significantly longer than female furcae at N2 ( $\mathrm{p}<0.001)$ and N3 ( $<<0.001)$. At the cypris stage, male larvae $(n=49 ; 276.5 \pm 6.9 \mu \mathrm{m})$ were also significantly longer than female larvae $(n=31 ; 238.4 \pm 5.1 \mu \mathrm{m})$ $(\mathrm{p}<0.0001)$.

\section{Morphology of the naupliar instars of S. carcini}

Discriminating morphological characters are summarized in Table 3. For each instar (N2-N5), these characters are identical between male and female nauplii.

\section{Nauplius 1 (N1)}

The N1 present an ovoid shape (Figs. 1a, 2a, 3a). Diffuse brown and red pigments are present in the cephalic region (Fig. 1a). Frontal horns are short, directed rearward (Figs. 1a, 2a), with a triangular shape and an apical 
Table 2 Dimensions $(\mu \mathrm{m})$ of the naupliar instars from single sex broods of Sacculina carcini Thompson, 1836

\begin{tabular}{|c|c|c|c|c|c|c|}
\hline \multirow[t]{2}{*}{ Instar } & \multicolumn{2}{|c|}{ Length, $\mu \mathrm{m}$ (mean $\pm \mathrm{SD})$} & \multirow[t]{2}{*}{$\mathrm{s}$} & \multicolumn{2}{|c|}{ Width, $\mu \mathrm{m}$ (mean \pm SD) } & \multirow[t]{2}{*}{$\mathrm{S}$} \\
\hline & Female & Male & & Female & Male & \\
\hline \multicolumn{7}{|c|}{ Larva-body } \\
\hline N2 & $250.8 \pm 9.7$ & $278.0 \pm 6.6$ & $* * *$ & $115.4 \pm 5.3$ & $127.2 \pm 3.4$ & $* * *$ \\
\hline N3 & $272.6 \pm 11.6$ & $303.6 \pm 9.8$ & $* * *$ & $121.5 \pm 5.9$ & $132.2 \pm 5.2$ & *** \\
\hline N4 & $285.1 \pm 8.2$ & $312.2 \pm 8.2$ & $* * *$ & $126.6 \pm 8.9$ & $142.8 \pm 2.8$ & *** \\
\hline N5 & $285.9 \pm 23.3$ & $315.0 \pm 12.7$ & $* * *$ & $136.5 \pm 11.5$ & $144.4 \pm 6.6$ & *** \\
\hline Cypris & $238.4 \pm 5.1^{\mathrm{a}}$ & $276.5 \pm 6.9^{b}$ & $* * *$ & - & - & \\
\hline \multicolumn{7}{|c|}{ Larva-Furca } \\
\hline N2 & $37.8 \pm 3.1$ & $43.0 \pm 5.0$ & ** & $22.0 \pm 1.6$ & $23.7 \pm 1.4$ & $* * *$ \\
\hline N3 & $48.4 \pm 6.5$ & $55.1 \pm 5.6$ & $* * *$ & $23.0 \pm 1.8$ & $26.8 \pm 1.9$ & $* * *$ \\
\hline N4 & $48.3 \pm 7.0$ & $47.2 \pm 7.0$ & $p=0.478$ & $24.3 \pm 2.2$ & $27.6 \pm 2.6$ & $* * *$ \\
\hline N5 & $38.4 \pm 6.8$ & $39.1 \pm 7.5$ & $p=0.8344$ & $21.8 \pm 1.8$ & $20.5 \pm 1.9$ & $* *$ \\
\hline
\end{tabular}

Single-sex broods, retrospectively sexed, were used. N1 were not found in naturally released broods ( $n=25$ for each instar N2-N5)

N2-N5 naupliar instars $2-5, p$ p value, ${ }^{* *} p<0.0001 ; * * 0.001, S$ significant, SD standard deviation

a $(n=31)$

b $(n=49)$

anterior spine, without terminal fringe (Fig. 3b). Each antennule has three portions (Fig. 1a) and bears five setae (S1-S5) (Figs. 2b, 3c), in which S1, S2, and S5 are shorter than S3 and S4, and S1 is conspicuous. Setae S1-S4 are inserted in the distal portion of the antennule. S5 is separated from the others on the distal edge of the second portion (Figs. 2b, 3c). The two furcal rami have a triangular shape and are short (Figs. 1a, 2a, c,3a, d).

\section{Nauplius 2 (N2)}

The N2 present an elongated shape (Figs. 1b, 2a, 3e). N2 are significantly shorter $(p<0.001)$ than N3, N4, and N5 within a same sex (Table 2). Brown and red pigments are located in the same region as N1 (Fig. 1b). Frontal horns are elongated, oriented laterally (Figs. 2a, 3e), and subdivided into three portions by two discrete grooves (Fig. 3f). Horns terminate with two spines, one anterior and one posterior, within the fringes of setae which are joined to each other (Fig. 3f). Setation of antennules is the same as in N1, with S1 conspicuous (Figs. 2b, 3g). The furcal rami are slightly thick (Figs. 1b, 2c, 3h) and without setules on the proximal third, but thin and with numerous long setules on the distal two-thirds (Fig. 3h). For each sex, the furcae are significantly shorter than in N3 and $\mathrm{N} 4(p<0.01)$.

\section{Nauplius 3 (N3)}

This naupliar instar has been overlooked in previous publications $[6,7]$. The N3 body shape is similar to that of N2 (Figs. 1c, 2a, 3i). Brown and red pigments are located in the same region as in N1 and N2 (Fig. 1c). Frontal horns terminate with two spines, as in N2, but the fringe setules are individualized (Fig. 3j). On the antennules, the second portion is swollen (Fig. 1c) and the S1 is inconspicuous (Figs. 2b, 3k). The furcal rami of N3 are slender and diverged (Figs. 1c, 2c, 3l). Within the same sex, N3 furcal rami are significantly longer than in N2. On the rami, setules are present on the distal two-thirds and evenly spaced (Fig. 31).

\section{Nauplius 4 (N4)}

The N4 shape is similar to those of N2 and N3 (Figs. 1d, $2 \mathrm{a}, 3 \mathrm{~m})$. Brown and red pigments are located in the same region as N1-N3 (Fig. 1d). Frontal horns of N4 (Fig. 3m, n) are identical to the horns of N3 (Fig. 3i, j). On the antennules, the second portion in N4 (Fig. 1d) is more swollen than in N3 (Fig. 1c) and the S1 is absent (Figs. 2b, 3o). A tubercle with setules is present between the two furcal rami, in ventral view (Figs. 2c, 3p).

\section{Nauplius 5 (N5)}

The body shape of N5 is more elongated than in N2-N4 (Figs. 1e, f, 2a, 3q). Future thoracopods are visible under the cuticle (Fig. 1e, f). At $52 \mathrm{~h}$, the young N5 present brown pigments in the cephalic region (Fig. 1e). At $104 \mathrm{~h}$, two spots of red pigments are present in the lateral part of the posterior region under the head shield of the late N5 (Fig. 1f). Frontal horns are identical to those in N4 (Figs. 1e, f, 2a, 3r). On the antennules, the second portion of the antennule is bulbous (Fig. 1e, f). S1 is absent and $\mathrm{S} 5$ is inconspicuous and inserted on the third antennular portion (Figs. 2b, 3s). A tubercle with setules is present between the two furcal rami, in ventral view (Figs. 2c, 3t). The telson presents two symmetrical and lateral notches, 
Table 3 Discriminating morphological characters of naupliar instars of Sacculina carcini Thompson, 1836

\begin{tabular}{|c|c|c|c|c|}
\hline & Shape & Fronto-lateral horns & Antennule & Telson and furca \\
\hline N1 & Ovoid & $\begin{array}{l}\text { Oriented backward, with an anterior terminal } \\
\text { spine, without terminal fringe }\end{array}$ & S1 conspicuous & Triangular and short rami \\
\hline N2 & Elongated & $\begin{array}{l}\text { Opened laterally. Two terminal spines. } \\
\text { Fringe of joined setae }\end{array}$ & S1 conspicuous & $\begin{array}{l}\text { Elongated, thick and close rami } \\
\text { First third without setule } \\
\text { Two distal third with numerous setules }\end{array}$ \\
\hline N3 & Elongated & $\begin{array}{l}\text { Opened laterally. Two terminal spines and } \\
\text { fringe of setae individualized }\end{array}$ & S1 inconspicuous & $\begin{array}{l}\text { Slender and diverged rami } \\
\text { Two distal third with spaced setules }\end{array}$ \\
\hline N4 & Elongated & $\begin{array}{l}\text { Opened laterally. Two terminal spines and } \\
\text { fringe of setae individualized }\end{array}$ & S1 absent & $\begin{array}{l}\text { One tubercle with setules between rami, } \\
\text { in ventral view }\end{array}$ \\
\hline N5 & Elongated & $\begin{array}{l}\text { Opened laterally. Two terminal spines and } \\
\text { fringe of setae individualized }\end{array}$ & $\begin{array}{l}\text { S1 absent, } \\
\text { S5 inconspicuous }\end{array}$ & $\begin{array}{l}\text { One large tubercle with setules between rami } \\
\text { Two symmetrical and lateral notches with spine }\end{array}$ \\
\hline
\end{tabular}

N1-5 naupliar instars 1-5, S1 antennular seta 1, S5 antennular seta 5

with a spine (Figs. 2c, 3t). At the base of the rami, sleeves can be present or absent, depending on the specimen (Fig. 3t).

\section{Chronology and synchronism of the larval development}

In the nine broods obtained under stress conditions, N1 were always present and one was a mix of $\mathrm{N} 1$ and $\mathrm{N} 2$. Among the 34 broods obtained under normal conditions in aquaria, N2 was generally the first instar sampled.

We studied larval development over time in seven different broods in natural conditions: two male, one female, and four of mixed-sex. Instar durations were similar among the three broods sampled every $4 \mathrm{~h}$ (one mixed-sex, two male) and were confirmed in the four other broods sampled less regularly (one female, three mixed-sex). Times of molts were indicated by the presence of exuviae in the aliquots. N2 lasted between 12 and $16 \mathrm{~h}$; N3 appeared between 12 and $16 \mathrm{~h}$ after release and lasted about $16 \mathrm{~h}$. N4 appeared between 28 and $32 \mathrm{~h}$ and lasted also about $16 \mathrm{~h}$. N5 appeared between 44 and $48 \mathrm{~h}$ and lasted about $64 \mathrm{~h}$. The cypris stage appeared between 108 and $112 \mathrm{~h}$ and were maintained up to two weeks at $4{ }^{\circ} \mathrm{C}$.

\section{Discussion}

\section{Five naupliar instars in S. carcini}

From our regular sampling of larvae every $4 \mathrm{~h}$, we identified five naupliar instars (N1-N5) whereas previous studies identified only four: N1-N4 [6, 7], which correspond to the N1, N2, N4 and N5 that we observed (Table 1). Giard [22] and Delage [23] also counted four molts until the cypris stage, i.e. four naupliar instars. The $\mathrm{N} 2$ and N3 are morphologically similar and last about $16 \mathrm{~h}$ each which may explain why they were described as a single instar previously. In other Rhizocephala species, four naupliar instars are usually described, but the frequencies of samplings were not specified [7, 24, 25]. The first description of five naupliar instars concerns a cold-water Rhizocephala, Briarosaccus tenellus [8]. Its development is very long (26-30 days at $5{ }^{\circ} \mathrm{C}$ ), which likely helped reveal the five naupliar instars. After this work, investigators began to count exuviae and fix rhizocephalan larvae samples more frequently. Five naupliar instars were subsequently described in other Sacculinidae species: Polyascus polygenea [9], Sacculina pilosella [10] and Heterosaccus papillosus [12]. Five instars were also found in Peltrogastridae: Peltogasterella sulcatus, $P$. gracilis [11] and Peltogaster reticulatus [26]. In contrast, some authors still found only four naupliar instars in Sacculina sinensis by sampling every day [27] and in Polyascus plana by sampling every $6 \mathrm{~h}$ [28].

In Thecostraca, which includes the Cirripedia, Ascothoracida and Facetotecta, six naupliar instars are usually found, but many taxa have fewer instars or the larvae hatch as cyprids [29]. When nauplius larvae are present, instar numbers vary from four to six in the cirripeds Acrothoracica [29, 30] and Thoracica species [31]. In Ascothoracida, which are all parasites in echinoderms and anthozoans [32], Ulophysema oeresundense present two naupliar instars [33] while Baccalaureus falsiramus present six naupliar instars [34]. All abbreviated developments in Thecostraca are linked to lecithotrophy, reducing the amount of energy allocated to larval development $[35,36]$. We suggest that the lecithotrophy and abbreviated development in Rhizocephala are adaptive responses to their parasitic life. Abbreviated development facilitates the life cycle progression of these parasites because invasive stages are attained more rapidly. For example, in the rhizocephalan Akentrogonidae, which are parasites of crustaceans, cypris larvae hatch directly [37]. However, there is a trade-off because hatching at the cypris stage does not permit large larval dispersion, although 

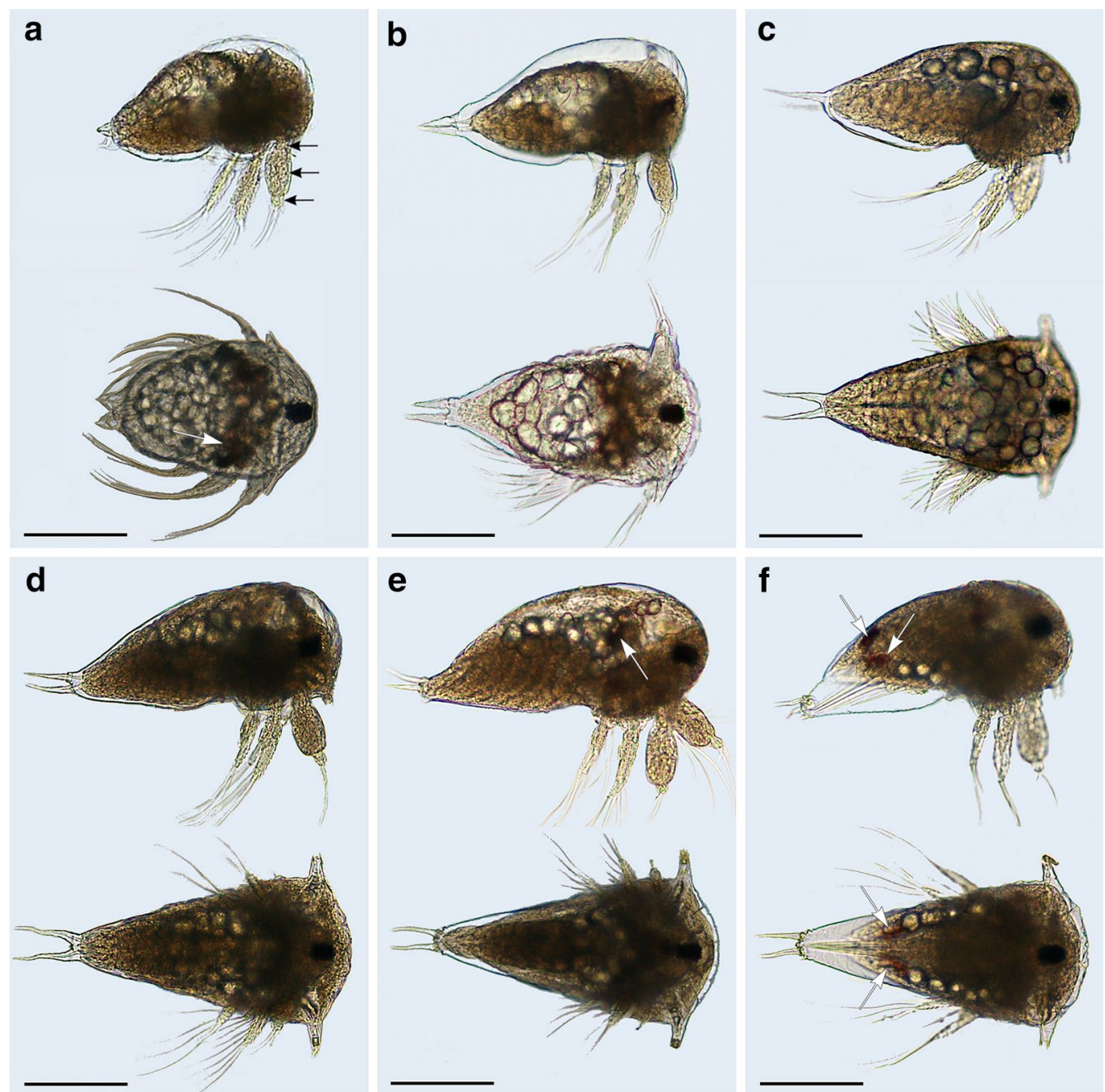

Fig. 1 Microscopic images of naupliar instars (male) of Sacculina carcini Thompson, 1836. Right lateral view (upper side) and ventral view (lower side): a N1 (prematurely released), three portions of the antennule (black arrow), red pigments in cephalic region (white arrow); b N2 (0 h) just released by the externa, with furca deployed, and frontal horns opened laterally; c N3 (20 h), with furcal rami diverged; d N4 (44 h); e young N5 (52 h) red pigments in cephalic region (white arrow); f late N5 (104 h), with two spots of red pigments beneath the posterior region of the head shield (white arrow). N1-N5: naupliar instars 1-5. Scale bar 100 m. Images with stereomicroscope (Olympus SZX7 associated with DP 20 camera)

dispersion time is reduced. Moreover, we suggest that Rhizocephala nauplii disperse passively towards the light, whereas competent cyprids actively seek their hosts [38].

\section{New insights on the morphology and dimensions of the naupliar instars of $S$. carcini \\ Measurements}

We compared our results to the previous work of Walker [6]. Our statistical analyses show that males are significantly longer than females from N2 to N5 (Table 2), which confirms previous observations. We also observed that our N4 and N5 length were shorter than the corresponding instars studied by Walker [6]
(Table 1). As our measurements differ from those of Walker [6], it is not possible to determine if the naupliar instar overlooked previously is N2 or N3. Body and furcal lengths are significantly different in these instars and can be used to discriminate N2 from N3 within a same sex.

\section{Morphological characters}

Compared to previous morphological observations [7], the two spines of the frontal horns in our observations are located anteriorly and posteriorly rather than dorsally and ventrally. In our observations, the second antennular portion of $S$. carcini swells progressively from N2 to N5, 

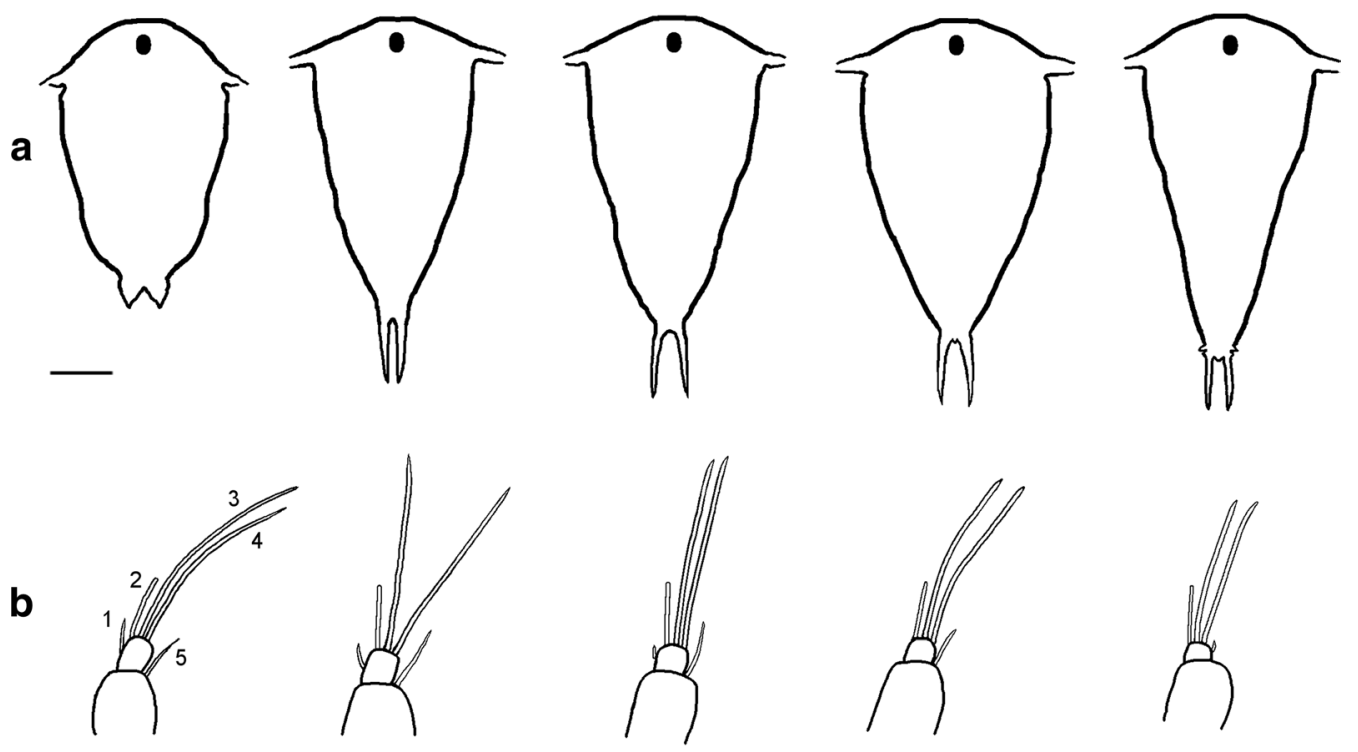

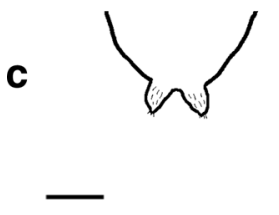

N1

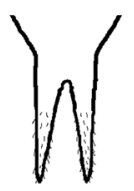

N2

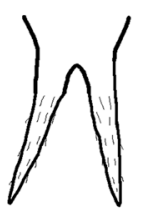

N3

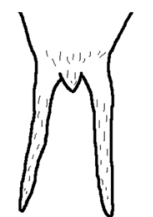

N4

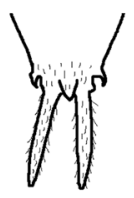

N5

Fig. 2 Morphological characters of tracing naupliar instars (male) of Sacculina carcini Thompson, 1836: a body shape in dorsal view, $\mathbf{b}$ antennular setation, c telson with furcal rami, dorsal view. N1-N5: naupliar instars 1-5. Scale bars a $50 \mu \mathrm{m}, \mathbf{b} 10 \mu \mathrm{m}, \mathbf{c} 20 \mu \mathrm{m}$

whereas Collis and Walker [7] found a swelling only in $\mathrm{N} 3$ and N4. Our N1 is identical to their N1 and our N4 is similar to their N3, except that we observe lateral spines only in N5. Our N5 is clearly the same larva as their N4. In addition, we found two previously undescribed N5 characters on the antennules. First, the postaxial seta (S5) is reduced compared to its size in N4 (Fig. 2b). Second, the insertion of S5 changes between the N4 and N5 instars from the second to the third antennular portion. S5 needs to be traced through the cuticle during molts, to ensure that it is the same seta from N1 to N5. Moreover, the red pigments in posterior region are useful for identifying late N5 larvae. By comparison, we can conclude that our N2 is similar to their N2. In both N2 descriptions, the preaxial seta (S1) is not reduced. In previous drawings of N2 (Figs. 1B and 24B in [7]), the second portion of the antennules is not swollen. Also, the furcal rami of their N2 are slightly thicker and shorter than in their N3 and present long and numerous setules. Thus, their
N2 corresponds to our N2. From these comparisons, we conclude that our N3 is a previously undescribed naupliar instar.

\section{Morphological characters of S. carcini larvae compared to other Rhizocephala larvae}

Morphological characters of the nauplii are important for rhizocephalan systematics and phylogeny [11].

\section{N1 characters}

An ovoid shape and frontal horns pointing rearward are $\mathrm{N} 1$ specific characters and are common to the N1 instar of all Rhizocephala [8-12], Thoracica [31], and Acrothoracica $[39,40]$.

\section{Fronto-lateral horns of N2-N5}

In S. carcini, frontal horns end in two spines and a fringe of setules between them ([7], this study). These two apical spines are specific to Sacculinidae [12]. In Peltogastridae, 
(See figure on next page.)

Fig. 3 Naupliar instars of Sacculina carcini, Thompson, 1836 from N1 to N5 (N2 male and N3-N5 female), scanning electron micrographs: a, e, i, $\mathbf{m}$ and $\mathbf{q}$ body shape in ventral view. Scale bar $50 \mu \mathrm{m} ; \mathbf{b}, \mathbf{f}, \mathbf{j}, \mathbf{n}$ and $\mathbf{r}$ : frontal horns. Double tip indicate anterior spine. Arrowheads indicate discrete grooves separating the horns in three portions. Scale bar $5 \mu \mathrm{m} ; \mathbf{c}, \mathbf{g}, \mathbf{k}, \mathbf{O}$ and $\mathbf{s}$ : antennular setation. Black arrow indicates a small tip at the basis of S5. Scale bar $5 \mu \mathrm{m} ; \mathbf{d}, \mathbf{h}, \mathbf{I}, \mathbf{p}$ and $\mathbf{t}$ : ventral views of telson with furcal rami. Large arrows indicate the tubercle between furcal rami. Little arrows show the notches with spine. Scale bar $10 \mu \mathrm{m}$

frontal horns are ornamented by one seta on the middle portion in P. gracilis and P. sulcata [11], and two setae in $B$. tenellus [8]. Apical fringe of setules are common to all Rhizocephala [8, 9, 11, 12, 28]. From our study, S. carcini frontal horns are divided into three portions at N2 (Fig. 3f). These subdivisions of the frontal horns were previously found only in Peltogastridae $[8,11]$.

\section{Morphology and setation of antennules}

The swelling of the second antennular portion of S. carcini has also been reported in other Rhizocephala species $[9,11,12]$. Swelling of antennules is also common in Thoracica [41] and is related to the formation of the cypris adhesive disc [42].

In $S$. carcini, as in almost all other Rhizocephala species, the N1-N3 naupliar instars present five setae on their antennules; S1 and S5 are shortest, S2 is intermediate, S3 and $\mathrm{S} 4$ are longest. Moreover, the $\mathrm{S} 1$ is reduced in size at N3 and disappears at N4 [9-12]. Briarosaccus tenellus is an exception because S1 disappears at the second instar [8]. In S. carcini, the S5 becomes inconspicuous at N5. To our knowledge, this reduction has not been described previously, but a progressive reduction in size between N2 and N4 appears in drawings of Heterosaccus papillosus antennulae [12]. The S5 at N2 presents a small spine at its base (Fig. 3g). A spine has also been described in the Rhizocephala observed in SEM: B. tenellus [8], P. sulcata and gracilis [11], and $H$. papillosus [12]. In the two latter descriptions, the authors proposed that it is a 6th seta. Nonetheless, in $S$. carcini, this tip is not present on all larvae, and when it is present, it is inserted randomly and directly on the S5. These observations suggest that S5 presents a variable morphology and that the tip could not be interpreted as a vestigial 6 th seta in $S$. carcini.

Our observations on $S$. carcini indicate that the setae $\mathrm{S} 1-\mathrm{S} 4$ are inserted on the apical portion. S5 is clearly inserted on the distal edge of the second portion at N1 and N2 (Fig. 3c, g), on the limit of the two last portions at N3 and N4 (Fig. 3k, o) and on the apical portion at N5 (Fig. 3s). This "jump" of setae between the antennular portions during the naupliar development has been previously described in cirripeds by Grygier [41].

\section{Telson and furca}

Furca and telson characters are useful for discriminating $S$. carcini naupliar instars at low magnification. The furca is longer at N3 than at N2 and could be useful for discriminating these instars within the same sex (Table 2). The furcal rami of the naupliar instars of S. carcini are almost as long as in S. pilosella [10] and in H. papillosus [12]. They are about one third shorter in P. polygenea [9].

In $S$. carcini, furcal rami are thick and short at N2, and thin and long at N3. We observe the same obvious characters in P. sulcata SEM images [11], suggesting that this character could be useful for identifying larval instars in several taxa.

The morphology of the telson (lateral spines in notches and tubercle) can also be used to discriminate the other naupliar instars (N1, N4 and N5) of S. carcini (Figs. 2c, $3 d, p, t)$. Lateral spines on the telson are visible only in our N5 (Fig. 3t). These spines are present earlier at N4 in P. sulcata and P. gracilis [11], and in S. pilosella [10].

The tubercle between the furcal rami is visible in ventral view at N4 and N5 in S. carcini. Tubercles are also present in the Sacculinidae $P$. polygenea [9] and $H$. papillosus [12] at the same instars, but not in the Sacculinidae S. pilosella [10] and the Peltogastridae B. tenellus [8] and P. gracilis [11]. This character seems variable within the rhizocephalans and even within the Sacculinidae, and could be a useful taxonomic character.

\section{N1, intermediate instar between embryos and larvae}

N1 larvae of $S$. carcini are only present in premature releases provoked by stress. Premature hatching of first instar larvae can also be provoked in the Acrothoracica species Trypetesa nassarioides [30] and in the Ascothoracida species Baccalaureus falsiramus [34].

From naturally released broods obtained in aquaria, the first larval instar of $S$. carcini is usually N2, with a mix of N1 and N2 observed only once. Giard [43] observed that, in Rhizocephala, larvae hatched as N1, but molted rapidly in N2, sometimes before their release out of the externa. Later, Delage [23] confirmed Giard's observations in S. carcini. These observations suggest that N2 is the most frequent instar released in the field by $S$. carcini. The N1 instar is very short in duration. N1 larvae develop normally, except if they have not molted after one day [23]. Mixtures of two larval instars at release have been observed in the Rhizocephala Lernaeodiscus porcellanae [44] and in the Thoracica Balanus amphitrite [45].

We suppose that in S. carcini, and perhaps in other cirripeds, mantle contractions help in the hatching at N1 


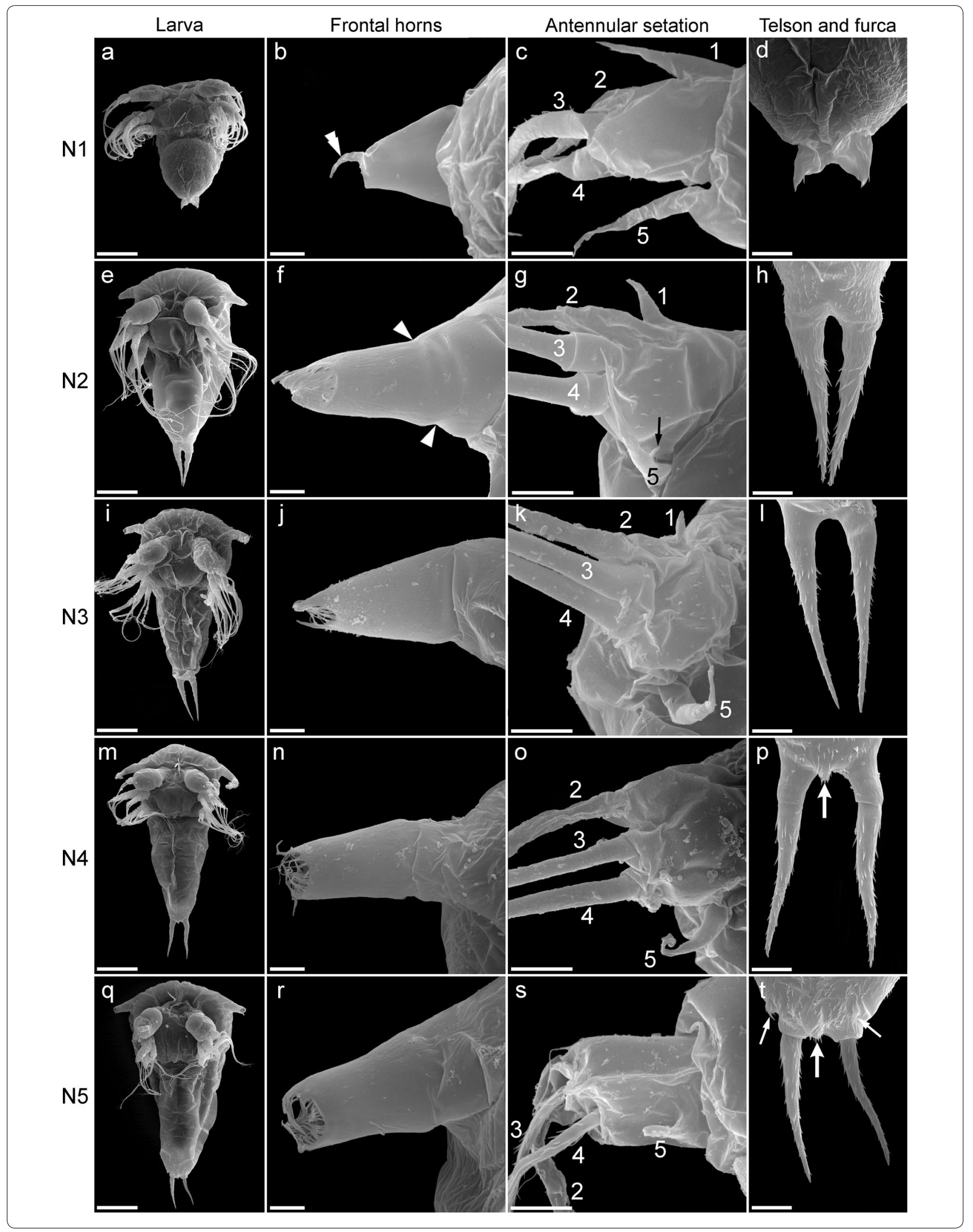


and the molting in N2, inside the externa, which allows a majority of $\mathrm{N} 2$ to be observed in normal releases.

\section{Synchronous development among larvae of a single brood}

This is the first study on $S$. carcini larval development with a precise chronology obtained by sampling every $4 \mathrm{~h}$. The larval development of S. carcini is remarkably synchronous within the same brood. Furthermore, the durations of naupliar instars are identical between broods obtained from different specimens. Synchronous larval development has been proposed for Rhizocephala $[8,46]$, but to our knowledge, has never been previously demonstrated until this work.

This synchronism resembles that observed in embryos of several species as the amphipod Parhyale hawaiensis [47]. We posit that, as in embryos, the lecithotrophy in nauplii allows the synchronous larval development and it may be that the synchronism of $S$. carcini is related to its parasitic lifestyle. The lecithotrophy in nauplii has appeared many times among crustacean taxa [48]. In several cases, lecithotrophy concerns parasitic species: in the Thoracica Anelasma squalicola [49] and probably in most of Ascothoracida and Facetotecta species [29], and in some Copepoda [50].

S. carcini may be a convenient model to study larval development. Its development table should allow further studies on the ontogenetic processes within an instar, rather than in successive instars. The $S$. carcini model permits studies on a continuous process, as previously recommended for arthropod developmental studies [51].

\section{Conclusions}

From precise monitoring of broods every $4 \mathrm{~h}$, we demonstrate that the life cycle of $S$. carcini includes five instars of nauplius larvae. The second and third naupliar instars were probably previously identified as a single instar either because their morphologies are similar or because they only last about $16 \mathrm{~h}$ each. We also describe these larval instars and present the morphological characters, such as the furca, the fronto-lateral horns, and the setation of the antennules that together discriminate these naupliar instars and identify $S$. carcini from other Rhizocephala species. Finally, we demonstrate that $S$. carcini larva development is reproducibly synchronized across different broods.

\section{Abbreviations \\ N1: nauplius instar 1; N2: nauplius instar 2; N3: nauplius instar 3; N4: nauplius instar 4; N5: nauplius instar 5.}

\section{Authors' contributions}

FT performed the experiments and analyses, and contributed to the writing of the article. NR co-directed the research with FA and participated in manuscript revisions. LB participated in the analyses and in manuscript revisions. FA co-directed the research with NR, interpreted the data and analyses, and was a major contributor to the writing of the manuscript. All authors read and approved the final manuscript and approved its submission for publication.

\section{Acknowledgements}

We are thankful to the SEM facility of the Direction des Collections located at the Muséum National d'Histoire Naturelle (Paris) for all the SEM images used in this article and Sylvain Pont for training in SEM. The authors also thank Dr. Adrien Bussard and Dr. Marc Eléaume for their advice in statistics and on R, and Dr. Kurt Liittschwager for reviewing the English text.

\section{Competing interests}

The authors declare that they have no competing interests.

\section{Availability of data and material}

The datasets during and/or analyzed during the current study are available from the corresponding author on reasonable request.

\section{Funding}

This research was funded by the research project grant "Actions Thématiques du Museum National d'Histoire Naturelle (MNHN): Cycles Biologiques and Formes".

Received: 22 July 2016 Accepted: 15 November 2016

Published online: 22 December 2016

\section{References}

1. Høeg JT, Lützen J. Crustacea Rhizocephala. Mar Invertebr Scand. 1985;6:92.

2. Cavolini F. Memoria sulla generazione dei pesci e dei granchi. Napoli: Socio di varie accademie; 1787 . p. 268.

3. Thompson JV. Natural history and metamorphosis of an anomalous crustaceous parasite of Carcinus maenas, the Sacculina carcini. Entomol Mag. 1836;3:452-6.

4. Anderson DT. Barnacles: structure, function, development and evolution. London: Chapman and Hall; 1994.

5. Øksnebjerg B. The Rhizocephala (Crustacea: Cirripedia) of the Mediterranean and Black seas: taxonomy, biogeography, and ecology. Isr J Zool. 2000;46:1-102. doi:10.1560/RCLC-NM2U-HV5L-6Q52.

6. Walker G. Observations on the larval development of Sacculina carcini (Crustacea: Cirripedia: Rhizocephala). J Mar Biol Assoc UK. 1988;68:37790. doi:10.1017/S0025315400043277.

7. Collis S, Walker G. The morphology of the naupliar stages of Sacculina carcini (Crustacea: Cirripedia: Rhizocephala). Acta Zool. 1994;75:297-303. doi:10.1111/j.1463-6395.1994.tb00966.x.

8. Walossek D, Høeg JT, Shirley TC. Larval development of the rhizocephalan cirripede Briarosaccus tenellus (Maxillopoda: Thecostraca) reared in the laboratory: a scanning electron microscopy study. Hydrobiologia. 1996:328:9-47.

9. Korn OM, Rybakov AV, Kashenko SD. Larval development of the rhizocephalan Sacculina polygenea (Crustacea: Cirripedia). Russ J Mar Biol. 2000;26:373-7. doi:10.1007/BF02759482.

10. Korn OM, Rybakov AV. Larval development in the rhizocephalan barnacle Sacculina pilosella. Russ J Mar Biol. 2001;27:177-9. doi:10.102 3/A:1016721603525.

11. Rybakov AV, Korn OM, Høeg JT, Waloszek D. Larval development in Peltogasterella studied by scanning electron microscopy (Crustacea: Cirripedia: Rhizocephala). Zool Anz. 2002;241:199-221. doi:10.1078/0044-5231-00070

12. Ponomarenko EA, Korn OM, Rybakov AV. Larval development of the parasitic barnacle Heterosaccus papillosus (Cirripedia: Rhizocephala: Sacculinidae) studied under laboratory conditions. J Mar Biol Assoc UK. 2005:85:921-8. doi:10.1017/S0025315405011896.

13. Høeg JT, Chan BKK, Rybakov AV. Rhizocephala. In: Martin JW, Olesen J, Høeg JT, editors. Atlas of Crustacean larvae. Baltimore: John Hopkins University Press; 2014. p. 111-5. 
14. Walker $\mathrm{G}$. The cypris larvae of Sacculina carcini Thompson (Crustacea: Cirripedia: Rhizocephala). J Exp Mar Bio Ecol. 1985;93:131-45. doi:10.1016/0022-0981(85)90154-6.

15. Høeg JT. The relation between cypris ultrastructure and metamorphosis in male and female Sacculina carcini (Crustacea, Cirripedia). Zoomorphology. 1987;107:299-311.

16. Ihaka R, Gentleman R. R: a language for data analysis and graphics. J Comput Graph Stat. 1996;5:299-314.

17. Bartlett MS. Properties of sufficiency and statistical tests. Proc R Soc A Math Phys Eng Sci. 1937;160:268-82. doi:10.1098/rspa.1937.0109.

18. Shapiro S, Wilk M. An analysis of variance test for normality (complete samples). Biometrika. 1965;52:591-611.

19. Kruskal WH, Wallis WA. Use of ranks in one-criterion variance analysis. J Am Stat Assoc. 1952;47:583-621.

20. Van der Waerden BL. Order tests for the two-sample problem and their power. Indag Math. 1952;14:458. doi:10.1016/S1385-7258(52)50063-5.

21. De Mendiburu F. Statistical procedures for agricultural research. R Package Version. 2014;1:1-6.

22. Giard A. Sur les Cirripèdes Rhizocéphales. C R Hebd Seances Acad Sci. 1873;77:945-8.

23. Delage Y. Évolution de la Sacculine (Sacculina carcini Thomps.): crustacé endoparasite de l'ordre nouveau des Kentrogonides. Arch Zool Exp Gén 1884;2:417-736.

24. Hawkes CR, Meyers TR, Shirley TC. Larval biology of Briarosaccus callosus Boschma (Cirripedia: Rhizocephala). Proc Biol Soc Wash. 1985;98:935-44

25. Walker G, Clare AS, Rittschof D, Mensching D. Aspects of the life-cycle of Loxothylacus panopaei (Gissler), a sacculinid parasite of the mud crab Rhithropanopeus harrisii (Gould): a laboratory study. J Exp Mar Biol Ecol. 1992:157:181-93. doi:10.1016/0022-0981(92)90161-3.

26. Kashenko SD, Korn OM. Combined effects of seawater temperature and salinity on development of the larvae of the rhizocephalan Peltogaster reticulatus (Crustacea: Cirripedia). Russ J Mar Biol. 2003;29:150-5. doi:10.10 23/A:1024664631438.

27. Chan BKK, Poon DYN, Walker G. Distribution, adult morphology, and larval development of Sacculina sinensis (Cirripedia: Rhizocephala: Kentrogonida) in Hong Kong coastal waters. J Crustac Biol. 2005;25:1-10. doi:10.1651/C-2495.

28. Tu TH, Chan BKK, Jeng MS. Larval development and sex ratio variation of Polyascus plana (Cirripedia: Rhizocephala), a parasite of the crab Grapsus albolineatus, in Taiwan. Bull Mar Sci. 2009:84:331-49.

29. Høeg JT, Chan BKK, Martin JW. Introduction to the Thecostraca. In: Martin JW, Olesen J, Høeg JT, editors. Atlas of Crustacean larvae. Baltimore: John Hopkins University Press; 2014. p. 97-9.

30. Le TurquierY. développement laravaire de Trypetesa nassarioides Turquier, cirripède acrothoracique. Arch Zool Exp Gén. 1967;108:33-47.

31. Chan BKK, Høeg JT, Kado R. Thoracica. In: Martin JW, Olesen J, Høeg JT, editors. Atlas of Crustacean larvae. Baltimore: John Hopkins University Press; 2014. p. 116-22.

32. Grygier MJ. Sous-classe des Ascothoracides (Ascothoracida Lacaze-Duthiers, 1880). In: Forest J et al, editors. Traité de zoologie: anatomie, systématique, biologie: VII. Crustacés: 2. Généralités (suite) et systématique. Paris: Masson; 1996. p. 433-52.

33. Brattström H. Undersökningar över Öresund. 33. On the larval development of the ascothoracid Ulophysema öresundense Brattström, Studies on Ulophysema öresundense 2. K Fysiogr Sallsk i Lund Förh. 1948;44:1-69.
34. Itô T, Grygier MJ. Description and complete larval development of a new species of Baccalaureus (Crustacea: Ascothoracida) parasitic in a zoanthid from Tanabe Bay, Honshu, Japan. Zool Sci. 1990;7:485-515.

35. Høeg JT. The biology and life cycle of the Rhizocephala (Cirripedia). J Mar Biol Assoc UK. 1995:75:517-50.

36. Høeg JT, Møller OS. When similar beginnings lead to different ends: constraints and diversity in cirripede larval development. Invertebr Reprod Dev. 2006;49:125-42.

37. Høeg JT, Rybakov AV. Revision of the Rhizocephala Akentrogonida (Cirripedia), with a list of all the species and a key to the identification of families. J Crustac Biol. 1992:12:600-9.

38. Pasternak Z, Blasius B, Abelson A. Host location by larvae of a parasitic barnacle: larval chemotaxis and plume tracking in flow. J Plankton Res. 2004;26:487-93. doi:10.1093/plankt/fbh040.

39. Utinomi H. Studies on the Cirripedia Acrothoracica-III development of the female and male of Berndtia purpurea Utinomi. Publ Seto Mar Biol Lab. 1961;9:413-46.

40. Kolbasov GA, Chan BKK, Høeg JT. Acrothoracica. In: Martin JW, Olesen J, Høeg JT, editors. Atlas of Crustacean larvae. Baltimore: John Hopkins University Press; 2014. p. 106-10.

41. Grygier MJ. Developmental patterns and hypotheses of homology in the antennules of thecostracan nauplius larvae (Crustacea). Acta Zool. 1994;75:219-34. doi:10.1111/j.1463-6395.1994.tb01210.x.

42. Nott JA, Foster BA. On the structure of the antennular attachment organ of the cypris larva of Balanus balanoides (L.). Philos Trans R Soc Lond B Biol Sci. 1969;256:115-34. doi:10.1098/rstb.1969.0038.

43. Giard A. Sur l'embryogénie des Rhizocéphales. C R Hebd Seances Acad Sci. 1874;79:44-6.

44. Høeg JT, Lützen J. Life cycle and reproduction in the Cirripedia Rhizocephala. Oceanogr Mar Biol. 1995;33:427-85

45. Anil AC, Desai D, Khandeparker L. Larval development and metamorphosis in Balanus amphitrite Darwin (Cirripedia; thoracica): significance of food concentration, temperature and nucleic acids. J Exp Mar Biol Ecol. 2001;263:125-41. doi:10.1016/S0022-0981(01)00280-5.

46. Queinnec E, Mouchel-Vielh E, Guimonneau M, Gibert J-M, Turquier $Y$, Deutsch JS. Cloning and expression of the engrailed. A gene of the barnacle Sacculina carcini. Dev Genes Evol. 1999;209:180-5. doi:10.1007/ s004270050242.

47. Browne WE, Price AL, Gerberding M, Patel NH. Stages of embryonic development in the amphipod crustacean, Parhyale hawaiensis. Genesis. 2005:42:124-49. doi:10.1002/gene.20145.

48. Martin JW, Olesen J, Høeg JT. The crustacean Nauplius. In: Martin JW, Olesen J, Høeg JT, editors. Atlas of Crustacean larvae. Baltimore: John Hopkins University Press; 2014. p. 8-16.

49. Frost WE. The nauplius larva of Anelasma squalicola (Loven). J Mar Biol Assoc UK. 1928;15:125-8.

50. Copepoda HuysR. In: Martin JW, Olesen J, Høeg JT, editors. Atlas of Crustacean larvae. Baltimore: John Hopkins University Press; 2014. p. 144-63.

51. Minelli A, Brena C, Deflorian G, Maruzzo D, Fusco G. From embryo to adult-beyond the conventional periodization of arthropod development. Dev Genes Evol. 2006;216:373-83. doi:10.1007/s00427-006-0075-6.

\section{Submit your next manuscript to BioMed Central and we will help you at every step:}

- We accept pre-submission inquiries

- Our selector tool helps you to find the most relevant journal

- We provide round the clock customer support

- Convenient online submission

- Thorough peer review

- Inclusion in PubMed and all major indexing services

- Maximum visibility for your research

Submit your manuscript at www.biomedcentral com/submit 